THURSDAY, MARCH I, I 894.

\section{THE REPORT OF THE GRESHAM UNIVERSITY COMMISSION.}

THE "Report of the Commissioners appointed to consider the Draft Charter for the proposed Gresham University in London, together with Dissentient and other Notes," is a document of sixty-three pages full of important matter from beginning to end. It bears evidence of very careful thought, and is worth attentive study.

The Commissioners accept at once two principles, both of which were included in, and one of which was peculiar to, the scheme of the Association for promoting a Professorial University in London. ${ }^{1}$ They lay it down that there should be one University only in the metropolis, and that the changes which they recommend should be effected not by Charter, but by legislative authority, and by the appointment of a Statutory Commission. They thus adopt the only satisfactory theoretical solution of the problem, and the only possible way of putting theory into practice. Every one is tired of the game in which the shuttlecock is tossed backwards and forwards from the University to the Colleges, from the Senate to Convocation. London and learning cannot wait indefinitely. The time has come when Parliament must arbitrate between conflicting views and interests.

The Commissioners also decide that the same University is capable of carrying on simultaneously systems of internal and external examinations, though Prof. Sidgwick has thought it right to express his disapproval of this conclusion.

They further propose that the scope of the University shall be enlarged in respect both of the subject-matter and the method of its teaching, so as to include six Faculties, viz. 'Arts, Science, Medicine, Law, Theology, and Music.

The first two of these are, of course, fundamental, and we hope that even if difficulties should arise with regard to the others, the foundation of a Teaching University in London, with the Faculties of Arts and Science only, will not thereby be prevented. If the existing University and the institutions of University rank which are chiefly interested in Arts and Science can be united, a most important result will have been achieved. The law of gravitation will in time do the rest.

We shall, therefore, confine ourselves chiefly to the proposals of the Commissioners with respect to Arts and Science, but a mere recapitulation of their recommendations would be of little interest unless the points of agreement with or divergence from previous schemes were indicated.

We propose, then, in the first instance to institute a comparison between the scheme of the Commissioners and three of the more important proposals which have been made in the course of the long discussion as to the best constitution for a Teaching University in the metropolis. The abortive Gresham Scheme may at once be put on one side. Its authors aimed at founding a

I This will be hereafter referred to as the Association Scheme. NO. 1270 , VOL. 49] second University in London. Everyone now agrees that there should be one only. The schemes which we select for our purpose are (I) the so-called Revised Scheme, which was approved by the Senate but rejected by the Convocation of the University of London; (2) the scheme approved in 1893 by Convocation ; and (3) the Association Scheme.

The "Revised Scheme" and that of Convocation differ from the others in that their authors contemplate the possibility of the University having direct relations with educational institutions outside the metropolitan area. As it is probable that the teaching operations of the new University will be confined to London, we shall pass over this point without further reference.

The Association and Convocation agree in fashioning the University out of materials which closely correspond to the "Chancellor, Masters, and Scholars" of our older seats of learning. On the other hand, the Revised Scheme and that of the Commissioners make a beginning with such bodies as the Senate, Convocation, \&c. The matter is not of fundamental importance, but it is necessary to refer to it as the phrase "the University shall consist of" is applied in different ways.

Putting this difference aside, the government of the University is distributed among various bodies named as follows :-

\begin{tabular}{c|c|c|c}
\hline Revised Scheme & Convocation & Association & Ccmmissioners \\
\hline $\begin{array}{c}\text { Senate } \\
\text { Convocation } \\
\text { Constituent Colleges } \\
\text { Faculties } \\
\text { Board of Studies }\end{array}$ & $\begin{array}{c}\text { Senate } \\
\text { Convocation } \\
\text { Professoriate } \\
\text { Faculties } \\
\text { Board of Studies }\end{array}$ & $\begin{array}{c}\text { Court } \\
\text { Professoriate } \\
\text { Ponvation }\end{array}$ & $\begin{array}{c}\text { Senate } \\
\text { Convocation } \\
\text { Academic Council } \\
\text { Faculties } \\
\text { Board of Studies }\end{array}$ \\
\hline
\end{tabular}

In what follows we shall use the word Senate to designate the Supreme Governing Body of the University. Its constitution under the different schemes is as follows :-

\begin{tabular}{|c|c|c|c|c|}
\hline Nominated or Elected by & $\begin{array}{l}\text { Revised } \\
\text { Scheme }\end{array}$ & $\underset{\text { tion }}{\text { Convoca- }}$ & $\begin{array}{l}\text { Associa- } \\
\text { tion }\end{array}$ & $\begin{array}{c}\text { Com- } \\
\text { missioners }\end{array}$ \\
\hline Crown & ro & 8 & 15 & 3 \\
\hline Ministers . & - & - & -3 & 5 \\
\hline Convocation . . & Io & 12 & 3 & 9 \\
\hline $\begin{array}{l}\text { Institutions represent. } \\
\text { ing : }\end{array}$ & & & & \\
\hline (a) Medicine - & 4 & 2 & 一 & 5 \\
\hline (B) Law $\therefore$ & 2 & 2 & - & 6 \\
\hline$(\gamma)$ Applied Science & - & - & - & 4 \\
\hline 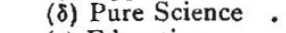 & - & - & - & 2 \\
\hline $\begin{array}{l}\text { (є) Education } \\
\text { Corporation, County }\end{array}$ & 10 & 2 & - & 5 \\
\hline $\begin{array}{l}\text { Council, \&c. } \\
\text { Teachers in University }\end{array}$ & - & 4 & 4 & 4 \\
\hline or Culleges $\dot{ }$ & I6 & ro & 25 & 22 \\
\hline itself & - & - & 4 & - \\
\hline Total & $5^{2}$ & 40 & $5 x$ & 65 \\
\hline
\end{tabular}

It will be observed that while but slightly reducing the absolute number of members claimed by Convocation 
and the Association for the interests with which they are specially connected, the relative importance of the representation of the graduates and the Professors has been reduced by the Commissioners.

The reduction has been about in the proportion of one-third to one-seventh in the case of Convocation, and one-half to one-third in the case of the Teachers.

We are inclined to think that Convocation is still over-represented, and should have been glad to see the principle admitted that half the entire Senate should consist of Teachers in the University. As far as these numbers are concerned, however, we accept the decision of the Commissioners as that of a body of men who have weighed most carefully the evidence submitted to them, and have evidently tried to do impartial justice.

A mere numerical comparison, such as the foregoing, does not, however, show all the points of difference between the schemes. The most fundamental divergen ce is in the proposed relations between the University and the chief Educational Institutions which already exist in London.

The Revised Scheme contemplated the establishment of Constituent Colleges, that is, institutions which the University recognised as giving teaching of University rank in some or all branches of learning. The Teachers in the Constituent Colleges who were thus recognised by the University were grouped into Faculties, to which bodies certain powers and privileges were given.

Over and above this the Senate was to have the power of entering into arrangements with any Constituent College by which it approved certain courses of study given in the College, accepted certificates of attendance at such courses, recognised special examinations conducted in the College by a College Professor and an adjoint Examiner appointed by the Senate, and gave Degrees to candidates who attended the specified courses and passed the special examinations. A Standing Committee of the Senate was to co-operate with the Constituent Colleges in the organisation and improvement of University Teaching in and for London, "including the establishment of Professorships." Inasmuch, however, as the Faculties were to consist of Teachers of the Constituent Colleges only, and no provision. was made for the admission to them of University Professors who were not connected with a Constituent College, it would appear that the University itself was not to be a Teaching Body.

As far as the Colleges are concerned, this was in effect the plan which has worked successfully in the Victoria University. The Colleges were to be independent, to appoint their own Professors, to find their own funds. If they succeeded they were to be recognised, and to share in the government of the University. Success would depend in part on the number of their students. Hence they were to be rivals, but the University would neither help nor hinder them. Equal privileges could be won by all. They would be impartially withdrawn from those who failed. The idea of recognising special examinations to suit special needs was an advance, and a very important advance, on the scheme of the Victoria University. A fundamental difference between the two Universities would, however, have been that, whereas the Victoria University can only give Degrees to candidates who have NO. I 270 , VOL. 49] passed through a College of the University, the University of London would have been able to give Degrees to all-comers, as well as to make special arrangements for students in Constituent Colleges.

The scheme of Convocation went a step further. It contemplated the possession by the University of independent laboratories, and therefore of a teaching staff of its own. It also proposed that Professorial Chairs in other Institutions should be endowed by the University on condition "that the appointment to such Chairs whenever a vacancy occurs should pass to the University." It was not stated whether the Professor so appointed should be subject to the University only, or whether he should be under the partial or exclusive control of the Governing Body of the College in which he worked. The Professorial Scheme was very similar. Every Professor of the University was to be appointed and paid by the University, and a Statutory Commission was to make arrangements with existing Institutions for complete or partial incorporation.

The Commissioners propose that certain Institutions, or departments in Institutions, shall be recognised as Schools of the University. The teachers in these Schools must be individually approved to secure a University status. The principle laid down by the Professorial Association, that Teaching Institutions as such are not to be represented on the Senate, is accepted, and thus the Constitution of the University is not in theory federal. On the other hand, places on the Senate are allotted to University College, King's College, the Royal College of Science, and the City and Guilds of London Institute, "regarded as important and wealthy public Corporations, or Societies, having and exercising wide educational aims and powers in connection with University education in London." The distinction is rather a fine one, but we gather that in the Commissioners' opinion King's College ought to have two representatives on the Governing Body, even if some theological difficulty led to its refusing to accept the position of a School of the University. The Commissioners decline to accept the idea either of immediate or of ultimate absorption of Educational Institutions as the basis of the University. But even if this is so, we think that they have gone too far in allotting a definite number of representatives to certain Teaching Institutions which happen at the moment to be the most important in London. The very existence of the Royal College of Science depends on the will of a Minister. We suppose that the City and Guilds Institute would collapse if the subventions it receives from the City Companies were withdrawn. The Commissioners themselves would surely be unwilling to throw any obstacles in the way of the complete absorption of University College by the University if in twenty years time it should itself desire it. Yet as matters stand any such change would involve a change in the Charter. It would surely be better to allot six representatives to the Governing Bodies of important Educational Institutions to be distributed in the first instance as the Commissioners propose, with the condition that the Senate may from time to time revise the list, subject to an appeal to the Privy Council. This at all events would secure greater flexibility. It is also possible that the Senate might 
delegate the government of institutions founded by the University to committees like the Kew Committee of the Royal Society, and, subject always to the approval of the Privy Council, there seems no reason why, if the number of independent Teaching Colleges were diminished, the places of their representatives should not be occupied by experts chosen from among the members of such Committees.

Among the Institutions which the Commissioners think should be at once admitted in whole or in part as Schools of the University, those which would be chiefly concerned with the Faculties of Arts and Science are the following :

University College.

King's College.

The Royal College of Science.

The City and Guilds of London Institute.

Bedford College.

And six Theological Colleges.

The University is to be able to appoint Professors and to found Teaching Institutions of its own, and it is also to have the power "to allocate funds for the enlargement and assistance of the teaching staff of recognised institutions, the extension of their buildings, the improvement of their equipment for teaching and research, and the endowment of University Professors, Readers, Lecturers, Demonstrators, or assistants, or for other purposes in connection with such institutions." It is to be "understood that in these cases the University will impose such terms and conditions as will secure to it a reasonable and proper amount of control over the educational resources thus provided, and will have the power of determining the duties of the University Chairs which it establishes or subsidises in any institution, and of regulating the fees payable for attendance on the lectures." "But," the Commissioners continue, "we do not think it necessary to lay down any rules which would fetter the discretion of the University in this matter. We take it for granted that it will be the endeavour of the University and of the institutions to organise a homogeneous system of University education, to utilise, to combine, and to economise existing resources to their fullest extent, and to supplement them in such a mode as will best serve the progress of knowledge."

In spite of this optimistic view of the future, it may be feared that the financial relations between the Colleges and the University will be difficult to adjust. Indeed, there are several points on which the Government will have to decide before putting the scheme into operation.

The University will have to be endowed by State or Municipal funds, if it is to be able either to subsidise or to add to the number of Colleges. If no such funds are provided, the state of things contemplated in the Revised Scheme will, in effect, be realised. The Colleges will be pecuniarily independent of the University, and since the University is to have no power of control except in return for subsidies, it will only be able to influence the "Schools" indirectly by visitation and by prescribing courses of study for the Degrees.

The Commissioners, however, evidently contemplate the large endowment of the University by the State. In this case it may have a more important part to play; but unless the control it claims in return for subsidies is

$$
\text { NO. I } 270, \text { VOL. 49] }
$$

sufficiently great to act as a deterrent, there will certainly be an undignified scramble for funds among the Colleges. It will be a miserable ending to the long controversy if the University is to be merely the guardian of a Government Grant fund, doling out one paltry sum here to build a second-rate laboratory, and forthwith bound to match it by another grant there, just to show that, like Justice, it is blind.

If the University establishes on a German scale a laboratory of its own, chiefly intended for post-graduate study, there will be an outcry against divorcing teaching from research. If it selects one existing Institution as that with which the laboratory is to be connected, it will be held to be neutralising the public-spirited efforts of the promoters of the others. If it tries to level up all round, it will achieve nothing really great. We do not say that such results must necessarily follow from the realisation of the scheme of the Commissioners, but the Commissioners themselves appear to have thought that the only way out of the difficulty was to appeal to the good feeling and good sense of all concerned. It is evident that the future of the University largely depends upon whether their appeal is successful, and upon the action of the Statutory Commissioners when appointed.

It might be possible to establish "spheres of influence" in the territory of Knowledge as well as in the Dark Continent. But whatever device be adopted, it cannot be made too clear that the Commissioners leave to the Statutory Commission and to the University itself the solution of the most difficult problems connected with its establishment. The character of the University will largely depend upon its relations with the Colleges, and their relations have yet to be defined.

We do not point to this "lacuna" in a spirit of adverse criticism. As nothing is known about the funds and resources the University will possess, it would probably have been useless for the Commissioners to have made detailed suggestions. But it is all-important that those who have most knowledge and experience in educational matters should agree upon some scheme more subtle than the suggestion that Colleges, like savages, should adhere to the good old rule-

$$
\begin{aligned}
& \text { "That he should take who has the power, } \\
& \text { And he should keep who can." }
\end{aligned}
$$

The relations of the Colleges and of the Teachers to the University are so intertwined that it is difficult to separate them. In what has been said, however, stress has chiefly been laid upon the former. We now turn to the position of the Teachers in the University.

The Association Scheme insisted that every Professor of the University should be " appointed and paid by the University." The Commissioners state that this "restricts within a narrower area than any other scheme which has been proposed to us the class of teachers who are permitted to share in the Government of the University." It is doubtful whether this was the intention of those who framed the Association Scheme. They undoubtedly desired that the University should be a Teaching University, and not merely a body with funds to be exploited by Teaching Colleges. Their proposal, therefore, was that all Professors teaching in the name and on behalf of the University should be directly responsible to it, and should therefore be paid by the 
University, whether the ultimate sources of their emoluments were provided by it or by a College. The regulation was probably intended to indicate a status, and not to restrict the number of those who attained $i$, and we hope it will be incorporated in the final scheme. But if this is so, it must be admitted that the Association's proposal is open to the second criticism which the Commissioners pass upon it. It created, they say, a single and undivided assembly of Teachers, on which, though in subordination to the Court, it conferred not only deliberative and consultative, but executive powers in matters which must necessarily involve much detailed and constant supervision.

In opposition to this the Commissioners group the Teachers into Faculties, and allow them to elect a very important body to be called the Academic Council. It is to consist, in addition to the Vice-Chancellor, of fifteen members, chosen as follows: Arts 4, Science 4, Medicine 3, Law 2, Theology I, Music I. The term of service is to be four years. Six to be a quorum. To this body will be entrusted the duty of regulating, subject to the Ordinances of the University, the teaching, examinations, and discipline of the University, and of determining what Teachers in any school of the University shall be recognised as University Teachers, and to what Faculties they shall be assigned.

In addition to these executive functions, it will be its duty to advise the Senate upon the affairs of the University, and particularly upon the assignment of funds for the erection or extension of buildings and the provision of teaching or equipment in connection with admitted Institutions or otherwise, and upon a number of similar points.

It is evident that by the establishment of this Council the Commissioners are prepared to give power to the Teachers of the University with no ungrudging hand. They assume that seats on the Academic Council will be held only by men of unquestioned reputation and experience, whose views will command the respect of the Senate. The Council is given very wide executive powers and the right to advise on matters of the utmost delicacy and importance. The only difficulty that we see is the possible intervention of College jealousy. It will be all-important that the men who are chosen shall be not only eminent in their own lines of work, but fair-minded and possessed of administrative powers. If once the easy expedient of taking turns is adopted, or if Professors working in University institutions are boycotted in favour of those connected with Colleges, or vice vers $\hat{a}$, the Açademic Council will be a failure. These considerations will probably suffice to prevent such evils arising; and if so, we think it possible that the Academic Council of the future University of London may develop into a body of the utmost importance, and that its views may acquire an authority which would never be attained by the decisions of a large assembly, many of the members of which would necessarily be comparatively unknown men. It will thus be seen that the Teachers of the University are to share in its government in two different ways. First, they are in their Faculties to elect one-third of the members of the Supreme Body or Senate; secondly, they are to elect fifteen of their number to form an Academic Council with wide execu- tive and advisory powers. It only remains to add that machinery is also provided by which this Counci\} is to be kept in touch with the main body of the Teachers, For this purpose Boards of Studies are to be appointed, the number and composition of which are to be determined by the Academic Council, with the proviso that not less than three -fourths of any Board are to be elected by the Faculty to which it belongs, and the remainder (if any) appointed by the Academic Council. These Boards are to have advisory powers, and it is laid down that no rule should be made with regard to or change effected in the curricula unless it has either been recommended by the Board or Boards of Studies of the Faculty concerned, or has been submitted to them by the Academic Council for consideration. It is also provided that in dealing with the courses of study to be pursued at any Institution it is reasonable that the Academic Council should first consult the authorities of the Institution. In neither case, however, is the Academic Council bound to conform itself to the view expressed by the bodies which it consults.

Such then, in general outline, is the scheme for the government of the new University proposed by the Commissioners.

It is in many respects bold and drastic. The existing Senate of the University of London is swept away. Thus, and in our opinion very rightly, it is made clear that the carrying into effect of the scheme of the Commissioners would be an absolutely new departure. It would be preceded by the complete dissolution of the Governing Body of the present University, no single member of which might find a place in the new order of things.

The Association, or some members of it, no doubt desired that a similar act of renunciation should precede the admission of a College to the University. Had this desire been fulfilled the whole problem would have been simplified, and the chances of success enormously increased. It is still possible for the Government to set the example in the case of the Royal College of Science. University and King's. Colleges are, however, the results of private effort. It would have been sheer confiscation to compel their Governing Bodies to resign their functions, though we believe that if they had sufficient confidence in the scheme proposed by the Commissioners to do so, their last service to learning and to education would surpass all the good work they have done in the past. Assuming, however, that they continue to exist as independent organisations, the most that can reasonably be urged is that the scheme shall throw no impediment in the way of absorption if all concerned should ultimately desire it. The Commissioners have evidently been anxious to leave the University as free as possible to develop in this as in any other direction. In one point only-and in that probably from inadvertence-have they imposed an un. necessary restriction. Representation on the Senate should not be allotted to particular Colleges, but to a class of Institutions, the list of which is capable of being revised with the approval of the Privy Council without a change in the Charter.

On the other hand, it must be admitted that the Commissioners, like the advocates of the Association Scheme,

No. I 270 , vol. 49] 
leave so much to be settled by the Statutory Commission that the ultimate character of the University is still very doubtful. Though non-federal in theory, it may be practically federal in fact, and it behoves those who are interested in the matter to do all in their power to protect it from the grave dangers which will beset the earliest stages of its career. The position assigned to Teachers, though not exactly that claimed by the Association, is so strong and so dignified that on this point we hope there will be no further controversy.

To sum up. Putting aside the relations of the University to Theology, Medicine, Law, and Music, the scheme of the Commissioners is the Revised Scheme, improved and modified so as to be much more closely in accord with the ideas of the Association. The question as to whether the University is, as far as Arts and Science are concerned, practically a federation of Colleges, is left to a Statutory Commission to decide. The main danger with which the University is threatened is jealousy between semi-independent Colleges. The only safeguard against this which the Commissioners suggest is that they take it for granted that everybody concerned will do his best "for the progress of knowledge." To which we heartily say "Amen."

\section{STEREOCHEMISTRY.}

Handbuch der Stereochemie. Unter Mitwirkung von Dr. Paul Walden herausgegeben von Dr. C. A. Bischoff. I. Band. (Frankfurt: H. Bechhold, 1893.)

TEREOCHEMISTRY grows apace. Thebirth of this youngest scion of the chemical family, which occurred about twenty years ago, when Van't Hoff and Le Bel published almost simultaneously their now famous memoirs, was not greeted with universal acclamation. The event excited at the time but little interest among English chemists, and when the young science was introduced, through F. Hermann's Lagerung der Atome im Raume, to the acquaintance of our German colleagues, it was regarded not without suspicion in some quarters. There was one chemist of high rank who denounced the Chimie dans l'Espace as "fanciful nonsense," as the outcome of " a miserable speculative philosophy, whose treatment of scientific subjects is not many degrees removed from a belief in witches and spirit-rapping." Stereochemistry, however, soon found a congenial home in the German laboratories, and flourished marvellously. About four years ago the young stripling was duly christened by Victor Meyer on the occasion of an address to the German Chemical Society, and thus received formal recognition as a legitimate nember of the chemical family. Since then three general treatises have been called for in order to chronicle the progress of this latest development of chemical science-the " Chemistry in Space" of Van't Hoff, translated into English and re-edited by J. E. Marsh ; Meyerhoffer's "Stereochemie,"a later translation into German of the same work with much additional matter, and the admirable "Grundriss der Stereochemie," by A. Hantzsch. Following quickly in the wake of these, we have, in the "Handbuch der Stereochemie," a much more elaborate and complete treatise, chiefly from the pen of Dr. C. A.
Bischoff, whose well-known indefatigable labours in the new field of research eminently qualify him for the serious task he has undertaken.

As explained in the publishers' announcement, stereochemistry has extended with such rapidity in recent years, and the numerous theoretical and experimental researches in this department are dispersed throughout so many different periodicals and pamphlets, that it is not easy for anyone who has not closely followed the subject from the outset, to obtain a general view of the development and present stand-point of the science. The object of the work before us is to remove this difficulty, and to attract more adherents to the new study. The book is further intended to exhibit the present position of all the problems which have been touched by stereochemistry, and to furnish a brief record of all the compounds which have any relation to optical and geometrical isomerism, so that it may serve as a convenient and reliable work of reference to the investigator.

The first volume of the treatise, extending to about 450 closely printed pages, comprises a general part, entitled "Die historische Entwickelung der Principien der Stereochemie," and the first subdivision of a special part, dealing with the relations of stereochemical theory to the phenomena of optical activity in organic compounds. The second volume, which is to appear shortly, will contain the remaining two subdivisions of the special part, which are to treat respectively of geometrical isomerism, and of the influence of intra-molecular space relations on chemical reactions.

The book has two distinct aims, which it is not easy to combine. As a work of reference the "Handbuch," we believe, fulfils all its claims, and will supply a much-felt want. The matter throughout is well up to date, the references to literature are copious, and the systematic account of all the known optically active organic compounds, which occupies more than half the volume, is the only complete collection of the kind we have at the present time. The organic chemist will understand the force of the commendation when we describe the book, from this point of view, as a stereochemical Beilstein, which will be indispensable in every laboratory where stereochemical research is being conducted. With respect, however, to the other purpose of the book, that of presenting a general picture of the development and present position of the science, the result is less satisfactory. The general part, which, judging from its title, was written with this end more particularly in view, is somewhat disappointing. The history of stereochemistry is an extremely fascinating subject; it contains all the elements of a good sensational scientific story, mysterious facts, wild speculations, ingenious hypotheses, beautifully verified predictions; but the subject as here presented is, to our mind, rather dry. The title of the chapter indicates that the development of the principles of stereochemistry is to be brought prominently into view; but we shall be surprised if the student, unless he is already pretty familiar with the literature of the subject, does not rise from its perusal, so bewildered in a maze of subtle speculation and conflicting hypothesis, as to conclude that stereochemistry has really no principles to develop. The introduction into a work of this kind of the speculation and hypothesis, to which stereochemical NO. I 270 , vor. 49] 